\title{
Indonesian Private University Lecturer Performance Improvement Model to Improve a Sustainable Organization Performance
}

\author{
Suryaman $^{1}$ \\ ${ }^{1}$ Faculty of Economy, Universitas Serang Raya, INDONESIA \\ Correspondence: Suryaman, Faculty of Economy, Universitas Serang Raya, INDONESIA \\ Received: November 14, 2017 \\ Accepted: January 10, 2018 \\ Online Published: January 16, 2018 \\ doi:10.5430/ijhe.v7n1p59 \\ URL: https://doi.org/10.5430/ijhe.v7n1p59
}

\begin{abstract}
Lecturer performance will affect the quality and carrying capacity of the sustainability of an organization, in this case the university. There are many models developed to measure the performance of teachers, but not much to discuss the influence of faculty performance itself towards sustainability of an organization. This study was conducted in an attempt to measure the performance of lecturers to support the sustainability of the university. A faculty performance assessment model is developed to see whether the performance of lecturers affect the sustainability of the university. The method used is descriptive and verification of data sample of 275 private university lecturers in Banten Province. Application of Structural Equation Model (SEM) was used to test the model and estimate hypothesis using LISREL Results showed that leadership, motivation, job satisfaction, and organizational commitment significantly and simultaneously affect the performance of lecturers with a contribution of $84 \%$. In addition, responsibility for the improvement of organizational performance based on indicators of commitment to the organization ranked highest score of the respondent's perception. This showed that the lecturers were highly committed to the organization. It is a great asset in the process of sustainability of an organization. In addition to the score of a continuing commitment to the organization shows lecturers should continue to be fostered in order to maintain the quality of organizational performance. This study shows that the performance of lecturers can support the sustainability of the organization.
\end{abstract}

Keywords: Performance, Leadership, Motivation, Job satisfaction, Organizational commitment

\section{Introduction}

\subsection{Introduce the Problem}

The results of the classification and ranking of universities by the government of Indonesia through the Ministry of Education and Research and Technology-DIKTI shows many universities, especially private sector has not been able to compete with state universities (http://www.ekonomi-holic.com/2015). Ironically, the opening of higher education in several provinces in Indonesia increased as demand for services will be the quality of education by society. However, the increase in quantity is not accompanied by their continuous quality improvement by individual private universities. One of components is the lecturers as a major resource in presenting high-quality education.

Improving the quality of faculty performance is a complicated problem faced by many universities in Indonesia. Performance measurement and quality assessment of lecturers are usually measured by three major indicators, namely, 1) education and teaching, 2) research and 3) community service. The third indicator is known as university's Tri Dharma. In fact, measuring performance based solely on these three indicators are not enough.

Several studies have analyzed a lot of faculty performance improvement based only on certain indicators, for example, only on the basis of job satisfaction (Hamzah et.al, 2010), the influence of motivation, organizational commitment, professional commitment (Trisnaningsih, 2003 In Nurika Restuningdiah) or even just based on indicators of education and teaching (Anak Agung Gde Agung and Irna Yuniar, 2014). There is no faculty performance measurement model that combines several indicators of the overall resulting in a complete performance assessment according to many relevant indicators. In addition, leadership factor in an organization is rarely included as one of the indicators is also able to boost the performance of lecturers.

Research carried out in an attempt to measure the performance of lecturers to develop a new model. The model in question is a combination of performance measurement models that have been used previously, such as job satisfaction, motivation, organizational commitment and commitment to the profession. In the model developed anyway, leadership indicators included in an organization that in previous studies rarely used as a gauge to see the 
performance of lecturers.

\subsection{Literature Review}

\section{Leadership Theory}

Leader in essence is a man who has the ability to influence the behavior of others in works by using the power (Daft, 2005) to influence, direct, instruct, motivate, inspire, power and give orders to other people or groups for supporting, responding, using, doing something, making others act, through communication to change more advanced organizational culture in order to achieve concrete results and common goals (Ivancevich et al., 2002). There are three dimensions of leadership variables generally accepted in the world of organizations (Fred E. Fiedler in Ivancevich et al, 2002: 433), namely:

a) The relationship between leaders and subordinates (X1.1). Consisting of sub dimensions: ability to respect the rights and obligations of each employee; warm communication between managers and staff; help solve the problem of employees; appreciate the work of subordinates; and be objective in the subordinate;

b) Structure of the task (X1.2), consisting of sub-dimensions: the simplicity of the work plan can be socialized; the realization of the work plan; and clarity of responsibility for the work;

c) Power (X1.3), consisting of sub-dimensions: ability to govern subordinates; firmness in making decisions; and improve the quality of subordinates.

\section{Work Motivation}

Motivation is the willingness to issue a high level of effort toward organizational goals, conditioned by its ability to collaborating behavior, giving directions to act, and triggers to continue to strive in order to deliver the performance and appreciation for the desired results and effort meet an individual need (Robbins and Judge, 2008). McClelland stated under working motivation has three important dimensions (Ivancevich et.al, 2002: 159), namely:

a) The need for achievement (X2.1), which consists of sub-dimensions: the effort to do well; effort to compete with other employees; efforts to develop themselves; and efforts to obtain recognition of the work;

b) The need for affiliation (X2.2), which consists of sub-dimensions: affiliated with a passion for the environment; spirit to work together; spirit to adhere to all the rules and always respect the leadership;

c) The need for power (X2.3), which consists of sub-dimensions: trying to keep him in esteem; an effort not to be underestimated; and the indispensable presence of others.

3. Job Satisfaction

Job satisfaction is the general attitude or a positive attitude toward work that arise based assessment of the employment situation or compare the number of rewards earned with which they expect or perceptions. Robbins and Judge (2008) states that, job satisfaction is a general attitude towards one's job, the difference between the number of rewards received by a worker and many rewards they believe they should receive. Job satisfaction is usually formed of three main variables, namely:

a) Employment relationship (X3.1), consisting of sub-variables: harmony in interacting with superiors; two-way communication; cooperation among lecturers ;, and openness and transparency of

b) The challenge (X3.2), consisting of sub-variables: complete the task; satisfaction in completing a task; responsible; discipline; and decision making skills.

c) Employment protection (X3.3), consisting of sub-variables: the protection of the Government; protection of labor agreements; and protection of insurance

\section{Organizational Commitment}

Wieneer defines commitment as a form of totality of faith normative for action where there is a meeting point between the organization's goals and interests, and individuals decided to behave as they believe that it is right and in accordance with the moral (Meyer and Allen, 2001 : 66). Organizational commitment is working attitude, emotion, belief, willingness that reflect the desires, needs, responsibilities, alignments and engagement to work hard, definite desire to stay in an organization and give our best effort, energy and time for a job or activity. Meyer and Allen (2001: 64) classified the organization's commitment in three aspects:

a) Affective commitment (X4.1), which contains a strong aspect of belief and accepts the values and objectives of the organization; loyalty to the organization; and willingness to use the effort for the sake of the organization. 
b) Commitment to continuous (X4.2), includes aspects into account the benefits to working within the organization; and account for the loss if left the organization.

c) Normative commitment (X4.3), includes aspects of willingness to work; and the responsibility to promote the organization.

5. Performance

Performance is defined as the ability to work in terms of quality and quantity (Khan et al, 2010: 297). This means that the performance is a feat achieved by a person working both in quality and quantity that are served by an employee in performing their duties in accordance with the responsibilities given to him. Relation to lecturer profession, the lecturer's performance can be interpreted as a result of the quality and quantity of work achieved a lecturer in implementing the Tri Dharma University that includes education and teaching, research, and devotion to the public in accordance with the responsibilities given to him (Bernardin and Russel, 2010). Indonesia in measuring the performance of lecturers is into three pieces based measurement of Teachers and Lecturers Law No. 14 of 2005:

a) Education and teaching (X5.1) consists of indicators to motivate students; compile a module or a textbook for students handle; makes planning for learning; provide structured tasks; interactions of faculty and students; and evaluate learning outcomes.

b) Research (X5.2) consists of indicators to conduct research independently or in groups; publish research results at scientific meetings and scientific journals; write a book reference of research results; and apply the results of research in the learning process.

c) Community service (X5.3) consists of indicators provide counseling to the public in accordance with the field; actively solve social and environmental problems; write community service work; and apply the results of the lectures through community service activities.

\subsection{Research Hypotheses}

To support the model developed in this study, the proposed five hypotheses as follows:

1. H-1: Does leadership affect the lecturer performance;

2. H-2: Does Work Motivation affect lecturer performance;

3. H-3: Does the job satisfaction affect lecturer performance;

4. H-4: Does the Organizational Commitment affect lecturer Performance;

5. H-5: Do leadership, motivation, job satisfaction, and organizational commitment, simultaneously affect the performance of lecturers Private Universities (PTS)..

\section{Method}

This research was conducted in several stages: first, Conceptual phase focused on efforts to formulate and limit the problem, reviewing the relevant literature, defines the theoretical framework, formulate hypotheses. Second, the design and planning phase that includes activities such as choosing the design of the study, identifying the population studied, specialized research methods to measure variables, designing a sampling plan, terminating and reviewing research plans, carry out pilot studies and make revisions. Third, the design of data collection instruments research and faculty performance improvement model in order to improve organizational performance on an ongoing basis, fourth, empirical stage where at this stage of data collection and preparation of data for analysis; and the fifth is the analytic phase containing activity data analysis and interpretation of the results and the testing of hypotheses that have been prepared. The flowchart research is shown in Figure 1. The design of faculty performance improvement model proposed private universities in this study as shown in Figure 2.

Research methods used in this study is the approach descriptive and verification. The research data used is the data sample lecturers from 21 private universities throughout Banten Province collected directly from the location empirically, in order to know the opinion of the population of the object being studied. There was a total population of 483 lecturers from 21 universities as shown in Table 1.

Based on population lecturer in Table 1, this study took a number of samples based on the results of the calculation with the formula amount indicator $55 \times 5$ dimensions, as many as 275 samples assuming the adequacy of the sample that must be met, amounting to 5 times the number of parameters to be estimated (Hair et. al.2008). Sampling was conducted using random sampling techniques. Data obtained by distributing questionnaires to 275 sample study. The types of questions used in the questionnaire are closed questions and structured where items of questions prepared by 
the indicator by using Likert's Summated Rating (LSR). Hypothesis testing is done by the three approaches, namely the analysis of univariate, bivariate, and multivariate.

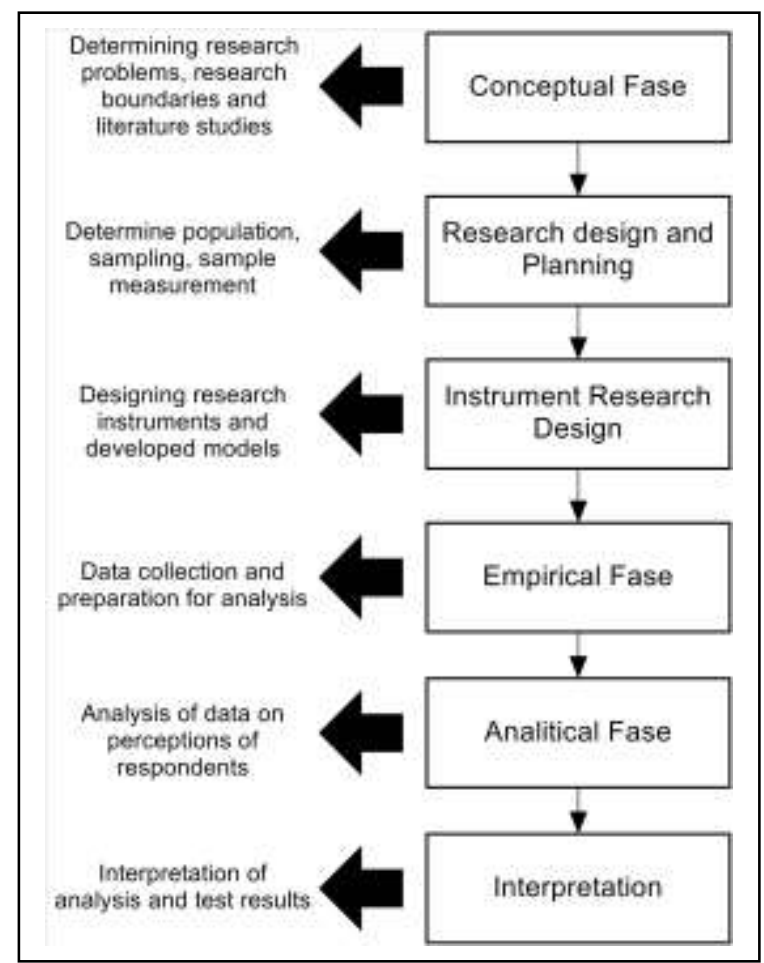

Figure 1. Research Flow.

Table 1. Total Population lecturer Each Private University

\begin{tabular}{cccc}
\hline College & $\begin{array}{c}\text { Number of } \\
\text { Lectures }\end{array}$ & College & $\begin{array}{c}\text { Number of } \\
\text { Lectures }\end{array}$ \\
\hline UNSERA & 133 & STMIK MUHAMADIAH BANTEN & $\mathbf{9}$ \\
UNBAJA & 19 & STISIP GUNA NUSANTARA & $\mathbf{0}$ \\
STIA MAULANA YUSUF & 13 & STIE DWIMULYA & $\mathbf{1 4}$ \\
STIKES FALETEHAN & 46 & AMIK SERANG & $\mathbf{6}$ \\
STT FATAHILLAH & 31 & AKADEMI TELEKOMUNIKASI & $\mathbf{4}$ \\
STIKOM WANGSA JAYA & 4 & NUSANTARA & $\mathbf{1 4}$ \\
STIE BANTEN & 35 & AKBID AISYIYAH & $\mathbf{8}$ \\
STKIP BANTEN & 0 & AKBID BHAKTI PURNA HUSADA & $\mathbf{9}$ \\
STIE BINA BANGSA & 56 & AKBID BINA HUSADA & $\mathbf{1 2}$ \\
STIM PRIMA GRAHA & 27 & PERBANKAN INDONESIA & $\mathbf{2 5}$ \\
& & POLITEKNIK PIKSI INFUT & $\mathbf{1 8}$ \\
& & POLITEKNIK BANTEN & $\mathbf{4 8 3}$
\end{tabular}




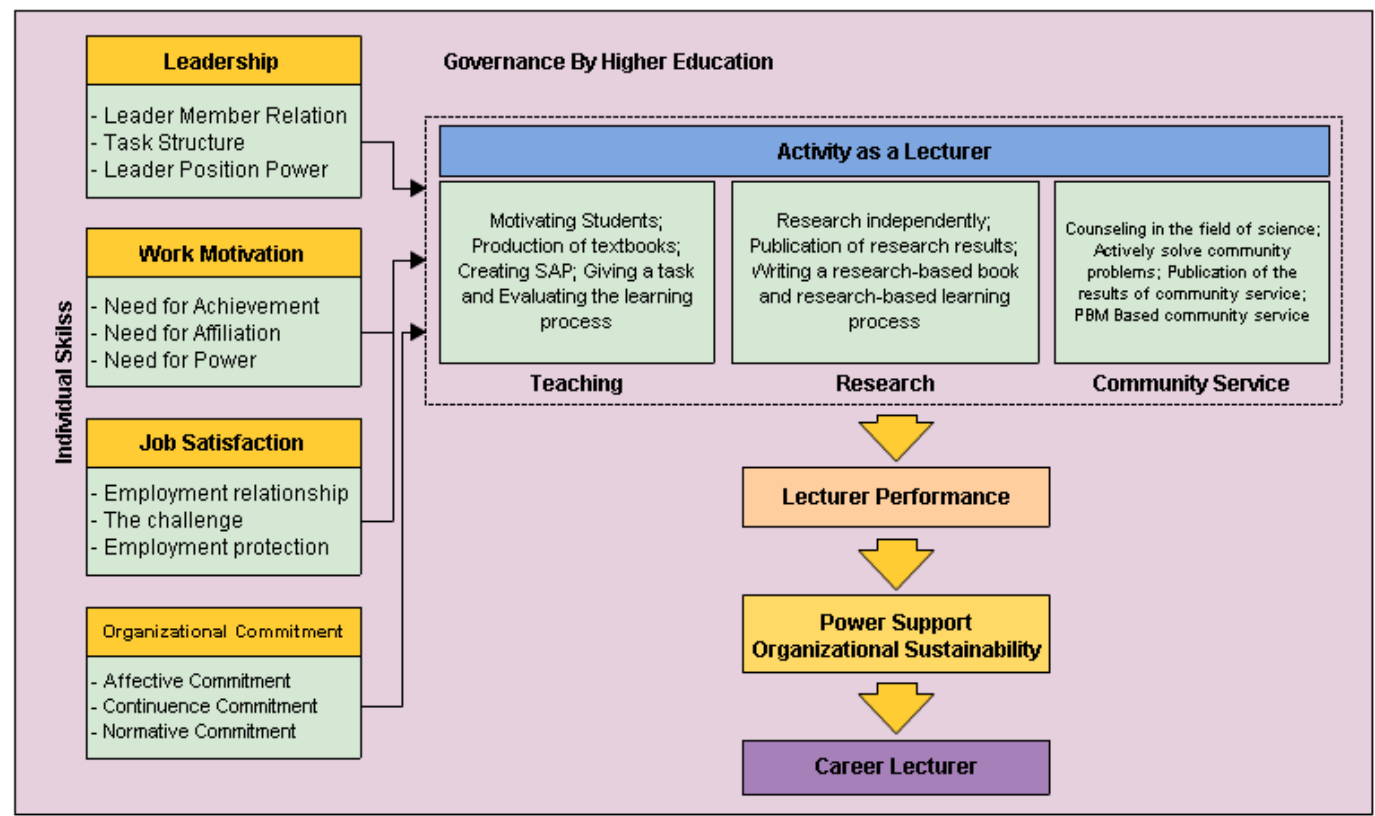

Figure 2. Proposed faculty performance improvement model

\section{Results and Discussion}

Before conducting an analysis of the data in an effort to interpret it into the research, the prerequisite to testing conducted research instruments. There are two approaches that do the prerequisite test validity and reliability testing of each instrument used. Test the validity of 40 respondents conducted on data from 275 samples to test whether the instruments used is feasible or not. Validity test results showed that the coefficient values or $r$ measurement for each variable is greater than the value of $r$ product moment, thus it can be said that the entire instrument in this study is worth valid. Research instrument validity test results are shown in Figure 3.

\begin{tabular}{|c|c|c|c|c|c|c|c|c|c|c|c|c|c|c|}
\hline $\begin{array}{c}\mathrm{r} \\
\text { tabel }\end{array}$ & 0.31 & 0.31 & 0.31 & 0.31 & 0.31 & 0.31 & 0.31 & 0.31 & 0.31 & 0.31 & 0.31 & 0.31 & 0.31 & 0.31 \\
\hline $\mathrm{X}_{1}$ & 0.67 & 0.53 & 0.74 & 0.70 & 0.76 & 0.80 & 0.84 & 0.75 & 0.80 & 0.63 & & & & \\
\hline $\mathrm{X}_{2}$ & 0.60 & 0.69 & 0.74 & 0.66 & 0.66 & 0.71 & 0.63 & 0.62 & 0.63 & 0.62 & 0.48 & & & \\
\hline$X_{3}$ & 0.60 & 0.59 & 0.63 & 0.71 & 0.81 & 0.63 & 0.73 & 0.76 & 0.81 & 0.76 & 0.80 & 0.73 & & \\
\hline $\mathrm{X}_{4}$ & 0.62 & 0.44 & 0.58 & 0.52 & 0.58 & 0.70 & 0.61 & & & & & & & \\
\hline $\mathrm{Y}$ & 0.40 & 0.56 & 0.68 & 0.49 & 0.58 & 0.41 & 0.79 & 0.78 & 0.74 & 0.79 & 0.74 & 0.71 & 0.79 & 0.75 \\
\hline
\end{tabular}

Figure 3. The results of the research instrument validity test

The reliability test is performed by calculating Cronbach Alpha coefficients of each item in a variable. Instruments used in the variable is said to be reliable if the Cronbach Alpha value of more than 0.6 (Nunnaly in Ghozali, 2002). The test results show that the reliability of the instrument's leadership has a value of Cronbach Alpha coefficients for 0915; motivation to work for 0856; 0.912 of job satisfaction; organizational commitment for 0.652 ; and the performance of lecturers for 0909 . Things reliability testing showed that all the instruments at variable research are very reliable. Therefore, based on tests conducted validity and reliability of the entire instrument in this study can be used to collect data. 
1. Descriptive Analysis

a) Leadership (X1)

Variable leadership is measured by three-dimensional i.e. working relationships between managers and staff (X1.1) using five questions, the task structure of the leadership (X1.2) using three questions, and power position (X1.3) using three questions. Results of the assessment of the perceptions of respondents obtained an average score of 3,933. The result of this perception can be grouped into either category. The indicator that has the highest score by respondents is an indicator of warm communication between managers and staff amounted to 4.280, while the indicator with the lowest score is shown on the indicator of appreciating the work of subordinates by 3.615. Based on the results of the assessment perception of respondents, it can be concluded that indicator of leadership is generally categorized to be used as a measurement of lecturer performance.

b) Work Motivation (X2)

The variable of work motivation is measured by three-dimensional achievement needs (X2.1) using the four questions, need for affiliation (X2.2) using the four questions and the need for power (X2.3) using three questions. The obtained measurement results on the perception of respondents under the variable work motivation had an average score 4.258 and grouped into the category of almost good. The highest indicator scores on these variables is shown by the indicator of maintaining friendships with co-workers with an average score of perception of 4.360, while the lowest indicator score is shown by indicators of attempt to obtain recognition of the work amounted to 3,735 .

\section{c) Job Satisfaction (X3)}

The variable of job satisfaction is measured by three-dimensional working relationship (X3.1) using the four questions, the challenge of working (X3.2) using five questions and dimensions of employment protection (X3.3) using three questions. The measurement results on the perception of job satisfaction variable had an average score of 3,856 and grouped into categories of almost good. The indicator with the highest score is shown by the two-way communication indicator amounted to 3,962, while the lowest score is shown by the indicator perception of insurance protection for 3303 .

d) Organizational Commitment (X4)

Organizational commitment is measured by the dimension of affective commitment (X4.1), continuous commitment (X4.2), and normative commitment (X4.3). The overall variable uses seven questions to see the perception of respondents. It shows that the overall dimension had an average of 4.037 or categorized at a higher level. The highest score of the indicator is the sub dimension of $\mathrm{X} 4.3$ which is the responsibility to promote the organization (normative commitment) amounted to 4.145 , while the lowest score is shown in the indicator X4.1 which is the loyalty to the organization (affective commitment) by 3,680 . The result shows that the normative commitment responsibility to promote the organization is an indicator of organizational commitment as the highest by 4.129 , followed by a continuous commitment for 4.040 and the lowest in affective commitment for 3.888 .

e) Lecturer Performance (X5)

Lecturer Performance is measured through education and teaching dimensions (X5.1), research (X5.2) and community service (X5.3) Score respondents in fourteen items to questions regarding the performance of the lecturer shows overall dimensions had an average of 4,101 and is classified in the category of high level. The highest score is in the dimension of X5.1 which is faculty attitudes to motivate students by 4.470 while the lowest perception is in the dimension of X5.2 by 3.993. Overall the average score for all three dimensions of respondents' perception of education and teaching, research and community service, respectively for 4.341, 4.074 and 4.067.

2. Verification analysis

a) Data analysis, structural and hypothesis testing

Data analysis was performed using SEM to 275 sample models lecturer at several universities in the province of Banten. The results of data processing distribution of questionnaires to the respondents are shown in Figure 4. 


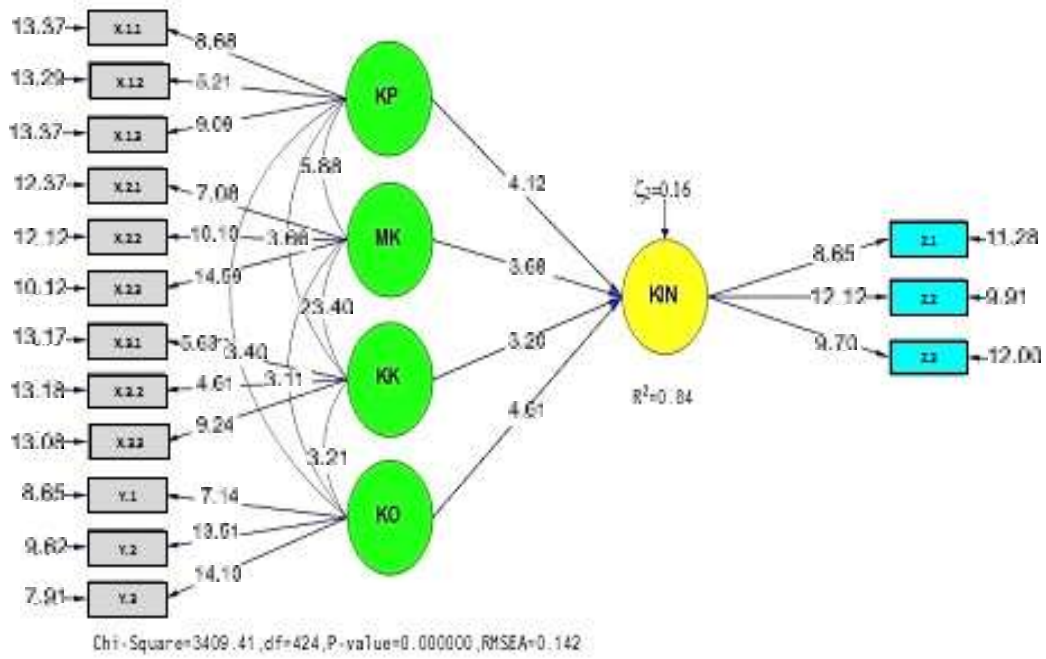

Figure 4. Results of the questionnaire distribution processing of the model using the SEM

The analysis of the results of the data processing using SEM stage is done to test the suitability and statistical tests, analysis of structural models WLS method. Structural model estimation results with the estimation method is shown in Figure 5.

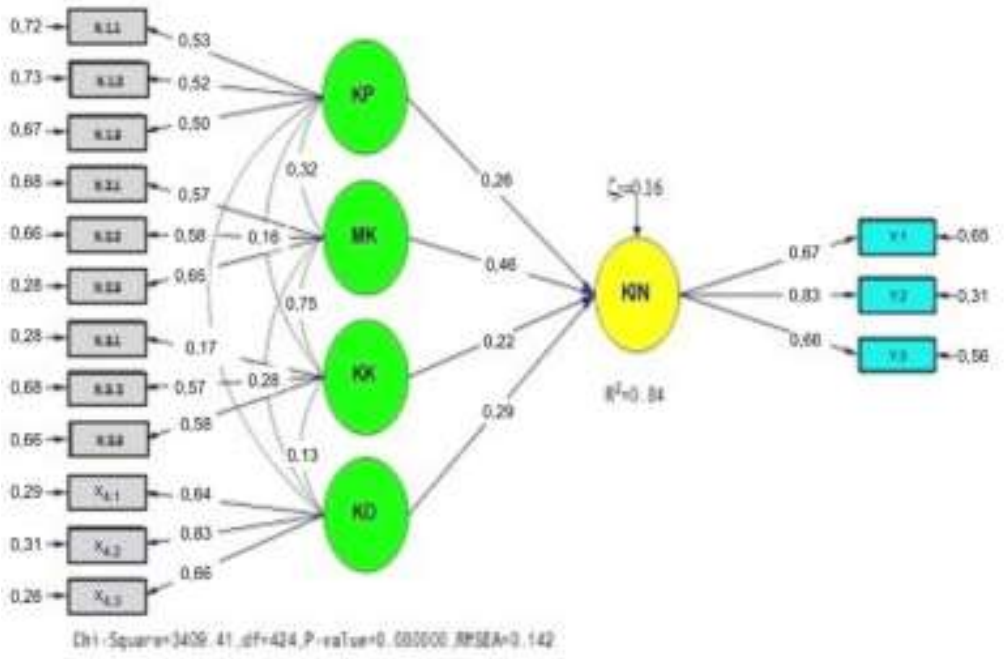

Figure 5. Results of statistical processing and conformance test structural models

In the following detailed explanation of the data analysis, structural and testing of the hypothesis of the study.

\section{H-1 Does leadership affect the performance of lecturers}

The data indicates a standard coefficient value of 0.26 , with a value of $4.12 \mathrm{t} .>\mathrm{T}$ table 1.96 . It can be concluded, leadership (X1) has a positive and significant impact on the Performance of Lecturer (X5).

Through the leadership variable factor analysis is known that the dimension of power position (X1.3), a powerful dimension that explains the organization's commitment is 0.57 . The second dimension is the dimension of the working relationship between the leadership of the faculty (X1.1) of 0.53 and the lowest dimensional structure of the leadership duties (X1.2) is 0.52. Thus, efforts to improve leadership can be prioritized to the power dimension position, the working relationship between the leadership of the faculty, the structure of the leadership duties. Leadership development that includes the working relationship between the leadership of the faculty, task structure, position of power, will be able to increase the support and encouragement of lecturers to work well. 


\section{H-2: Does work motivation affect Lecturer performance}

The standard coefficient value is 0.44 , with a value of $3.68 \mathrm{t}$.> $\mathrm{T}$ table 1.96 . It can be concluded, work motivation (X2) has a positive and significant impact on the performance of lecturers (X5). In other words, partial model H-6 is acceptable.

Through factor analysis of work motivation is known that the dimensions of the power requirement (X2.3) is the strongest dimension, the second dimension is the need for affiliation (X2.2) and the lowest dimension is the dimension of achievement needs (X2.1). Thus, efforts to increase the motivation can be prioritized on the dimensions of power requirements, dimensions affiliated needs, and achievement needs. Development of employee motivation which includes the need achievement, need for affiliation, need for power, will be able to increase the support and encouragement of lecturers to work well.

\section{H-3: Does the job satisfaction affect the performance of lecturers}

Based on the data processing standard coefficient of 0.22, with a value of $3.20 \mathrm{t} .>\mathrm{T}$ table 1.96 . It can be concluded, the dimensions of job satisfaction (X3) has a positive and significant impact on the performance of lecturers (X5). In other words, partial model $\mathrm{H}-7$ is received.

Through the analysis of variable factors of job satisfaction in mind that the dimensions of the power requirement (X3.3) is the strongest dimension, the second dimension is the need for affiliation (X3.2) and the dimensions of the lowest dimension of achievement needs (X3.1). Thus, efforts to increase job satisfaction can be prioritized on the dimensions of power needs, affiliated needs, and the dimensions of achievement needs. The development of job satisfaction includes dimension of labor relations, labor challenges, employment protection dimension, will be able to increase the support and encouragement of lecturers to work well.

\section{H-4: Does the Organizational Commitment affect on Lecturer Performance}

The standard coefficient value is 0.29 , with a value of $4.61 \mathrm{t}>\mathrm{t}$ table 1.96 . It can be concluded, the dimensions of organizational commitment (X4) has a positive and significant impact on the performance of lecturers (X5).

Through the commitment variable factor analysis known that the dimension of normative commitment (X4.3) is the strongest dimension, the second dimension is the continuous commitment (X4.2), and the lowest dimension is the affective commitment (X4.1). Thus, efforts to increase the commitment can be prioritized on the dimensions of normative commitment, continuous commitment, and affective commitment.

Development of job satisfaction on organizational commitment covering dimension affective commitment, continuous commitment, normative commitment would be able to increase the support and encouragement of lecturers to work well. This finding is consistent with research Khan et.al. (2010) concluded that there is a positive and significant relationship between organizational commitments to employee performance. the findings of Kumar and Mr. Rose, (2009), which concluded that there is a significant relationship between organizational commitment to employee performance. And the results of this study are also in accordance with the findings of the findings I Ketut R Sudiarditha, (2010) which concluded that, organizational commitment significantly influence employee performance. The higher organizational commitment affect the higher employee performance, and vice versa. and Suliman (2002) concluded that to influence organizational commitment to employee performance.

H-5: Does leadership, motivation, job satisfaction, and organizational commitment, simultaneously affect the performance of lecturers Private Universities (PTS)

The equation of the model of faculty performance through value standard estimate is as follows:

$$
\mathrm{X} 5=0: 26 * \mathrm{X} 1+0: 44 * \mathrm{X} 2+0: 22 * \mathrm{X} 3+0: 29 * \mathrm{X} 4, \mathrm{R} 2=0.84
$$

Coefficient determination equal to 0.84 , while the value of $\mathrm{F}$ (354 375)> F table> 2605, Ha accepted which means there is positive and significant variables of X1, X2, X3 and X4 simultaneously Against X5 variable, meaning that the variable $X 1, X 2, X 3$ and $X 460 \%$ affect the influence of $X 5$, while $16 \%$ are influenced by other factors.

Through SLP revleksi dominant explain the performance (X5) is Variable of motivation (X2) premises coefficient of standard at 0:44 and revleksi domination explains the performance variable (X5) is the dimension of research amounted to 0.86 , thus the dimensional requirement of power capable of explaining Motivation (X2) then a major concern in an effort to raise the performance (X5)

Figures R square implies that the variation is explained by the performance of lecturers is leadership, motivation, job satisfaction, and organizational commitment of $84 \%$, and the remaining $16 \%$ influence of other factors not examined in the model. Another factor mentioned among others, competence, organizational climate, organizational culture, 
and others. Because the estimates on this structural model using regression approach, amounting to $193.30 \mathrm{~F}$ count> F table 2372, the H1 simultaneous models for this 9th hypothesis is accepted.

The variables that explain the more dominant motivation of faculty performance is variable with a standard coefficient of 0:44, followed by the organizational commitment variable standard coefficient 0.29 , then the leadership of 0:26 with standardized coefficients are the last 0:26 of job satisfaction with standardized coefficients of $0: 22$. Faculty performance is built with leadership development, motivation, job satisfaction and organizational commitment. Lecturers who have high performance are the lecturers who have high motivation, high commitment, leadership that can develop human resource well as those with high job satisfaction.

Based on the weighting coefficient factor, it is noted that the performance of research is the dimension that has the highest coefficient of 0.87 , followed by education and teaching dimensions of 0.67 , then the last dimension is the service to the community 0.66 . From this dimension can be seen that the dimensions of the study is the most dominant dimension represents variable of faculty performance, followed from the education and the teaching and community service.

When viewed from an average of descriptive, it is known that the average performance of the lecturers are low that the dimensions of community service (X5.3), which only amounted to 4,067, followed by research (X5.2) of 4,074, and education and teaching. (X5. 1) amounted to 4,341. The results of this study, according to the findings of Sulis Rahmawanto (2012) concluded that there is influence between leadership, motivation, work satisfaction, and organizational commitment to the performance of lecturers $(0: 22 \times 0: 29)=0.064$.

b) Analysis of Application of Model

Based on the descriptive analysis and testing respondents' perception to the five variables (leadership, motivation, job satisfaction, organizational commitment and performance of lecturers), it shows that these variables can be used for supporting components of the model increased performance of lecturers in universities, This can be seen from the values of the perception that most of the respondents classify each variable into categories of good and almost good which is not much different perception of the value of one variable to another variable.

Relation to the indication of sustainable performance improvement organization, the results demonstrate organizational commitment variable perception of value perception is at a high level, meaning it can be said to be good. In addition, responsibility for the improvement of organizational performance based on indicators of commitment to the organization ranks highest score of the respondent's perception. This shows that the lecturers are highly committed to the organization that shelter is a great asset in the process of sustainability of an organization. In addition, the score of a continuing commitment to the organization shows lecturers should continue to be fostered in order to maintain the quality of organizational performance

\section{Conclusion}

Based on research conducted, it can be concluded as follows:

1. Based on the results of hypothesis testing, proven leadership and significant positive effect on the employment of lecturers, especially the performance of research, with elements of leadership with such dominance reflection position power factor (X1.3), while the, on the performance of lecturers with the reflection of domination in the form of research performance (X5.2). This shows that the improvement of leadership in private university will lead to increasing faculty performance improvement.

2. Based on the result of hypothesis test, work motivation has positive and significant influence on lecturer performance, especially research, with work motivation element with reflection of power factor (X2.3), meanwhile, on lecturer performance with reflection dominance Model Performance X5.2). This shows that the improvement of work motivation in private universities will be faster.

3. Based on hypothesis test result, job satisfaction has positive and significant influence on lecturer performance, especially research, with work performance by reflecting domination of work factor (X3.3), meanwhile, on lecturer performance with reflection dominance Model performance (X5.2). This shows that there is an increase in job satisfaction at private universities, there will be emptiness of lecturer performance

4. Based on the result of hypothesis test, proven organizational commitment has positive and significant influence on lecturer performance, especially research, with organizational commitment element with reflection domination factor of normative commitment (X4.3), meanwhile, on lecture performance with reflection dominance of Performance Model (X5.2). This shows that the increase in organizational commitment to private universities will be faster. 
5. Based on the results of hypothesis testing, proven leadership, motivation, job satisfaction, and organizational commitment simultaneously and positively to the performance of lecturers, with $84 \%$ contribution while the remaining $16 \%$ bear other variables, while the most dominant variable namely motivation variables with Reflections domination Factor of power requirement (X2.3). This shows positively the improvement and improvement of leadership, motivation, job satisfaction, and organizational commitment simultaneously with good performance, independent of exogenous and endogenous variables that have intervening partial criterion, because of the smaller influence. There are two variables that have direct influence namely the leadership and motivation to performance.

\section{References}

Agung, Anak Agung Gde dan Yuniar, Irna. (2014). Desain Indikator Dan Implementasi Penilaian Kinerja Dosen Pada Sistem Informasi. Seminar Nasional Sistem Informasi Indonesia, 22 September

Bernardin, H.John and Russel. (2010). Human Resource Management. New York: McGraw-Hill.

Daft, Richard L. (2005). The Leadership Experience, South Western: Venderbilt University.

Ghozali, Imam. (2002). Aplikasi Analisis Multivariate dengan Program SPSS, Universitas Diponegoro,Semarang.

Hair, Joseph F.et. al. (2008). Multivariate Data Analysis. New Jersey: Prentice-Hall,Inc. Diunduh tanggal 25 September 2014 dari http://pdfcrop.in/ebook/title/hair-et-al-2006-multivariate-data-analysis.htm

Hamzah, Uno. (2010). Teori Motivasi dan Pengaruhnya. Jakarta : Bumi Aksara.

Ivancevich Michael T, Konopaske Robert, Matteson John M. (2002). Organizational Behavior and Management. seventh edition, Houston: McGraw Hill.

I Ketut R. Sudiarditha. (2010). Pengaruh Kompensasi dan Kompetensi Kerja terhadap Komitmen Organisasi serta Dampaknya pada Kinerja Karwayan. Jurnal Riset Manajemen Sains Indonesia, 1(2), Desember 2010 hal 208-2012 Jakarta: FE Universitas Negeri Jakarta.

Khan, Muhammad Riaz, et.al. (2010). The Impacts of Organizational Commitment on Employee Job Performance. European Journal of Social Science, 15(3), 292-298.

Meyer, John P dan Natalie J Allen. (2001). A three Component Conceptualization of Organizational Commitment. Human Resource Management Review, 1(1), 1991, 61-89. https://doi.org/10.1016/1053-4822(91)90011-Z

Rahmawanto, S. (2012). Pengaruh Kepemimpinan, Motivasi Kerja, Kepuasan Kerja, dan Komitmen Organisasi terhadap Kinerja Guru Madrasah Tsanawiyah di Magelang tahun 2012. Doctoral thesis. Yogyakarta: UIN Sunan Kalijaga. in bahasa

Restuningdiah, Nurika. (2009). Pengaruh Komitmen Profesional terhadap Kepuasan Kerja Akuntan Pendidik melalui Komitmen Organisasional, Jurnal Ekonomi Bisnis| Tahun 14| Nomor 3| Nopember.

Robbins dan Judge. (2008). Perilaku Organisasi, Edisi Duabelas, Penerbit Salemba Empat: Jakarta.

Rose, Kumar, dan Pak. (2009). The effect of Organizational Learning on Organizational Commitment, job Satisfaction and Work Performance. The Journal of Applied Business Research-November/December 2009 25(6), 55-66. https://doi.org/10.19030/jabr.v25i6.995

Suliman, A.M.T. (2002). Is It Really A. Mediating Construct The Mediating Role Of Organizational Commitment in Work Climate-Performance Relationship. Journal Of Management Development, 21(3), 170-183. https://doi.org/10.1108/02621710210420255

Undang-Undang Republik Indonesia Nomor 14 Tahun 2005, tentang Guru dan Dosen. 